\title{
Sites of secretion of bioactive compounds in leaves of Dracocephalum moldavica L.: anatomical, histochemical, and essential oil study
}

\author{
Marta Dmitruk $^{1} \cdot$ Aneta Sulborska $^{1}$ (D) $\cdot$ Beata Żuraw ${ }^{2} \cdot$ Ernest Stawiarz $^{1} \cdot$ Elżbieta Weryszko-Chmielewska $^{1}$
}

Received: 2 April 2019 / Revised: 11 September 2019 / Accepted: 12 September 2019 / Published online: 5 October 2019

(c) The Author(s) 2019

\begin{abstract}
Dracocephalum moldavica L. is an aromatic plant emitting intense lemon scent. The aboveground parts of the plants constitute raw material for medicine and food industry. In contrast to the comprehensively investigated trichomes, there are only few studies of the histochemical characteristics of the leaves of essential oil-bearing plants from the family Lamiaceae. The present study shows the micromorphology, anatomy, and histochemistry of the leaves of the analysed species. The research aimed to determine the location of essential oil and other specialised metabolites in leaf tissues. The investigations of fresh and fixed material were carried out with the use of light, fluorescence, and scanning electron microscopy. Additionally, the content and composition of essential oil in the leaves were determined with the GC/MS method. The leaf epidermis had non-glandular unbranched trichomes and three types of glandular trichomes: peltate as well as long and short capitate trichomes. The results of the histochemical assays showed positive reactions to lipids and to some secondary compounds such as essential oil, terpenes, phenolic compounds, and flavonoids in all types of the glandular and non-glandular trichomes. The same compounds were found in the epidermis cells of the leaves. The results of the present study indicate that the intense smell of the leaves is associated with emission of essential oil not only by the glandular and non-glandular trichomes but also by the leaf epidermis cells. The main components in the essential oil $(0.10 \%)$ include geranial, neral, geraniol, nerol, and trans-myrtanol acetate. Since D. moldavica has been used as an adulterant of Melissa officinalis L., the anatomical traits of leaves and the essential oil composition in both species were compared in the study.
\end{abstract}

Keywords Dragonhead $\cdot$ Epidermis $\cdot$ Essential oil $\cdot$ Lamiaceae $\cdot$ Leaf $\cdot$ Specialised metabolites $\cdot$ Structure $\cdot$ Trichomes

\section{Introduction}

The genus Dracocephalum represents the family Lamiaceae (Labiatae) and comprises approximately 40 species, a majority of which originate from the mountains of Central Asia, mainly from the Altai (Hegi 1965; Brickell 1999). These are mostly perennials and, more rarely, annual plants or subshrubs. Dracocephalum moldavica L. is naturalised in eastern and central Europe (Dastmalchi et al. 2007). In Poland, it is a cultivated species and can be found in natural habitats as a "runaway" from gardens (Rutkowski 2006). The species was introduced into the gardens of Europe as

Aneta Sulborska

aneta.sulborska@up.lublin.pl

1 Department of Botany and Plant Physiology, University of Life Sciences, Akademicka 15, 20-950 Lublin, Poland

2 Department of Industrial and Medicinal Plants, University of Life Sciences, Akademicka 15, 20-950 Lublin, Poland early as in the second half of the sixteenth century. Referred to as "Melissa aut Cedronella" by Gesner in 1561, it was next named "Melissa moldavica and Melissa turcica" (Hegi 1965). Given its aroma and therapeutic properties, it was used as an adulterant of Melissa officinalis L. (Amin 1991).

D. moldavica (Moldavian dragonhead) comprises herbaceous, annual, strongly aromatic plants with an agreeable lemon scent. The plants are 30-60 cm high. The lower leaves are petiolated with crenate-serrate margins, whereas the upper leaves are sessile and have spiny-serrate edges. The large flowers with a corolla length of $20-25 \mathrm{~mm}$ are usually purple-blue and, less frequently, light blue or white (Hegi 1965; Dmitruk and Weryszko-Chmielewska 2010; Dmitruk et al. 2018).

D. moldavica is regarded as an ornamental, medicinal, cosmetic, seasoning, and apiary plant. It is a surrogate of tea and an ingredient of bird feed mixtures (Hegi 1965; Dastmalchi et al. 2007; Lipiński 2010; Dmitruk et al. 2018). 
D. moldavica leaves, stems, and flowers are covered by numerous glandular and non-glandular trichomes (Dmitruk and Weryszko-Chmielewska 2010), as in many other species from the family Lamiaceae (Ascensão et al. 1995; Corsi and Bottega 1999; Chwil et al. 2016; Janošević et al. 2016; Haratym and Weryszko-Chmielewska 2017; Tozin and Rodrigues 2017). Previous studies of D. moldavica trichomes on the leaves conducted by other researchers with the use of the available methods, mainly LM, demonstrated different findings. Kubiak (1959) described three types of nonglandular trichomes and four types of glandular trichomes on the leaves of this species; but no illustrations were presented. Lyapunowa et al. (1975) and Shavarda et al. (1990) distinguished non-glandular trichomes and two types of glandular trichomes on D. moldavica leaves, and the former authors showed them in illustrations. Telepova et al. (1992) presented SEM electronograms of a fragment of the leaf surface with visible non-glandular trichomes and three types of glandular trichomes. The data on non-glandular trichomes reported in the studies mentioned above coincide, but there are evident differences in the description of glandular trichomes. All the authors reported the presence of short capitate trichomes with a two-celled head, whereas Kubiak (1959) described short capitate trichomes with a four-celled head. Some authors observed long capitate trichomes on the leaves of the species (Telepova et al. 1992; Dmitruk and Weryszko-Chmielewska 2010). The analysed reports showed large differences in the number of head cells of peltate trichomes $(8,9,10,12$, or 16 cells).

Glandular trichomes in plants representing different families produce essential oils containing specialised metabolites characterised by biological activity; therefore, they are applied in medicine and have potential applications in food (Duke 1994; Burt 2004; Miguel 2010). D. moldavica has been applied for many years in traditional medicine, given its analgesic, anti-inflammatory, anticonvulsive, antispasmodic, and wound healing effects (Nikitina et al. 2008; Sultan et al. 2008). Tincture of dry herb has been used to treat heart disease, blood pressure, congestion, angina, liver disorders, tracheitis, atherosclerosis, neuralgia, migraine, headache, and toothache (Kakasy et al. 2002; Nikitina et al. 2008; Sultan et al. 2008; Shuge et al. 2009; Jiang et al. 2014).

Research reports have demonstrated antioxidant, anti-bacterial, antigenotoxic, and cardioprotective activity of metabolites from this species (Dastmalchi et al. 2007; Nikitina et al. 2008; Jiang et al. 2014; Aprotosoaie et al. 2016). It has been found that the essential oil of $D$. moldavica is secreted by several types of secretory trichomes located on various parts of shoots: stems, leaves, and flowers (Kubiak 1959; Dmitruk and Weryszko-Chmielewska 2010). However, the histochemical properties of these trichomes have not been investigated so far. Given the multiple applications of $D$. moldavica herb associated with the presence of aromatic compounds, we have focused on investigations of the structure and histochemical traits of the leaves of the species. We focused particular attention on the epidermis and its structures (trichomes, stomatal complexes). Additionally, we have carried out chemical analyses to determine the content and composition of essential oil contained in the herb.

\section{Materials and methods}

Plant material - The D. moldavica leaves and bracts used in the anatomical and phytochemical analyses were collected from plants with purple-blue flowers in the Botanical Garden of Maria Curie-Skłodowska University in Lublin $\left(51^{\circ} 26^{\prime} 20.7^{\prime \prime} \mathrm{N}, 22^{\circ} 51^{\prime} 37.8^{\prime \prime} \mathrm{E}\right)$. The investigations were carried out in August in 2016 and 2017 when the plants were in full bloom. Seeds yielding the plants included in the study were collected in 2015 and 2016, respectively.

Preliminary observations of the leaf and bract morphology and the distribution of glandular and non-glandular trichomes were performed with the use of a stereoscopic microscope STM 800 (Microlab). Large glandular (peltate) trichomes on the abaxial surface of bracts $(n=10)$ and leaves $(n=10)$ were counted. Photographs were taken.

Light microscopy - Handmade preparations Bracts from 14th node and leaves from the seventh node were collected from fresh material of 20 randomly chosen specimens. Handmade cross sections were made at the widest area of the leaf blade using razor blades. After de-aeration of the sections (by embedding in a water-glycerine mixture in a 1:1 ratio for $24 \mathrm{~h}$ ), glycerine preparations were made and viewed under a light microscope (Nikon). The thickness of the lamina of the bracts $(n=34)$ and leaves collected from the middle part of the stem $(n=34)$ was measured as well as the length of each type of trichomes $(n=50)$. Photographic documentation was prepared with a Coolpix 4500 (Nikon) camera coupled to an Eclipse 400 (Nikon) light microscope.

Preparation of permanent slides Leaves were collected from the same sites as described above. Leaf blade fragments were fixed in $2 \%$ paraformaldehyde and $2.5 \%$ glu-

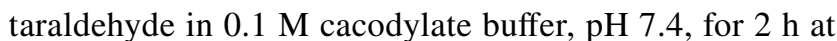
room temperature and for another $12 \mathrm{~h}$ at $4{ }^{\circ} \mathrm{C}$. After $24-\mathrm{h}$ rinsing in $0.1 \mathrm{M}$ cacodylate buffer at $4{ }^{\circ} \mathrm{C}$ and fixing in $1 \%$ $\mathrm{OsO}_{4}$, the samples were transferred to redistilled water and stained in a $0.5 \%$ aqueous uranyl acetate solution. Next, the material was dehydrated in ethanol series (30, 50, 70, 90, $96 \%$ ) and immersed in anhydrous ethanol twice for $30 \mathrm{~min}$. Finally, the samples were infiltrated and embedded in acrylic resin (LR White) (Karnovsky 1965). After dehydration, the samples were embedded in Spurr Low Viscosity resin for $12 \mathrm{~h}$ at a temperature of $70{ }^{\circ} \mathrm{C}$. The material prepared in this way was cut into semi-thin (approximately 15 - $\mu \mathrm{m}$-thick) 
sections using a Reichert Ultracut S microtome. The preparations were stained in $1 \%$ methylene blue with $1 \%$ azure $\mathrm{B}$ in a $1 \%$ aqueous sodium tetraborate solution (O'Brien and McCully 1981).

Histochemical analyses - Leaf and bract tissues, including glandular trichomes, were characterised histochemically using fresh free-hand sections and the following histochemical tests: toluidine blue $\mathrm{O}$ for pectins, tannins, and other phenolic compounds (Baker 1966; Ramalingan and Ravindranath 1970); ferric trichloride for phenolic compounds (Gahan 1984); Sudan IV for total lipids (Johansen 1940); Nadi reagent for terpenes (David and Carde 1964); and aluminium trichloride as a fluorochrome under ultraviolet light with $\mathrm{Cy}_{5}$ filter, for flavonoids (Charrière-Ladreix 1973). Additionally, fluorescence microscopy analyses were performed under ultraviolet light for detection of phenolic substances (autofluorescence in blue colour) (Mabry et al. 1970). Standard control procedures for all sections were carried out in glycerine slides, which were examined and photographed with a Coolpix 4500 (Nikon) camera coupled to an Eclipse 400 (Nikon) light microscope.

Scanning electron microscopy - Fragments of leaves were fixed at a temperature of $4{ }^{\circ} \mathrm{C}$ for $12 \mathrm{~h}$ in a $2 \%$ solution of glutaraldehyde with $2.5 \%$ paraformaldehyde in $0.75 \mathrm{M}$ phosphate buffer ( $\mathrm{pH}$ 6.8). Next, the plant samples were rinsed with the same buffer and then dehydrated in an ethanol series and critical point dried in liquid $\mathrm{CO}_{2}$ using a K850 (Emitech) Critical Point Dryer. Then, they were coated with a layer of gold (to a thickness of $20 \mathrm{~nm}$ ) using a sputter coater K550X (Emitech). The micromorphology of the surface of epidermis cells of the leaf was examined under a Tescan Vega II LMU (Tescan) scanning electron microscope at an accelerating voltage of $30 \mathrm{kV}$ (Stpiczynska et al. 2013).

Phytochemical analyses - Essential oil isolation The analyses were carried out on $200 \mathrm{~g}$ of fresh leaves, which was distilled in $400 \mathrm{ml}$ of water for $30 \mathrm{~min}$ in Deryngtype apparatus, according to the Polish Pharmacopeia VIII (2008). The volume of the essential oil was measured; next, the oil was dried over anhydrous sodium sulphate and stored at $4{ }^{\circ} \mathrm{C}$ until gas chromatographic determination of its composition.

Gas chromatography-mass spectrometry (GC-MS) The chemical composition of the essential oil was analysed using the GC-MS instrument ITMS Varian 4000 GC-MS/ MS (Varian, USA) equipped with a CP-8410 auto-injector and a $30 \mathrm{~m} \times 0.25 \mathrm{~mm}$ i.d. VF-5 ms column (Varian, USA), operating in electronic ionisation mode at $70 \mathrm{eV}$ and mass range from 40 to $1000 \mathrm{Da}$. The scan time was $0.80 \mathrm{~s}$. The split ratio was $1: 100$, and the volume injection was $1 \mu \mathrm{L}$. The column temperature was initially kept at $50{ }^{\circ} \mathrm{C}$, and then gradually increased to $250{ }^{\circ} \mathrm{C}$ at a rate of $4{ }^{\circ} \mathrm{C} \mathrm{min}-1$. This temperature was held for $10 \mathrm{~min}$. Helium was used as carrier gas $\left(0.5 \mathrm{~mL} \mathrm{~min}^{-1}\right)$.

Gas chromatography-flame ionisation detection (GCFID) In our study, also a Varian 3800 Series (Varian, USA) instrument with DB-5 column (J\&W, USA), operated under the same condition as GC-MS, was used.

Individual volatile compounds were identified based on the comparison of their Kovats retention indices with $\mathrm{n}$-alkane series and mass spectra with those of authentic samples, National Institute of Standards and Technology (NIST), and with data available in the literature (Van Den Dool and Kratz 1963; Adams 2001; 2007; Mass Spectral Library 2008).

\section{Results}

Leaf morphology - Stem leaves There are two leaves growing from each node below the inflorescence on the Dracocephalum moldavica stem (Fig. 1a). The teeth on the leaf blade margins are rounded at the apex (Fig. 1b). The abaxial leaf surface is slightly glossy and is covered with sparse trichomes (Fig. 1e).

There are many non-glandular trichomes at the leaf margins and along the veins on the abaxial surface (Figs. 1e, $2 a-c)$. Peltate secretory trichomes are distributed relatively regularly in the depression of the intercostal zones of the abaxial surface of the leaves (Figs. 1e, 2a, e, 3g-j). The number of these trichomes per unit area is $1.1 \cdot \mathrm{mm}^{-2} \pm 0.16$.

Additionally, both the adaxial and abaxial leaf surfaces bear capitate secretory trichomes (Figs. 2a, d, f, 4f). In general, four types of trichomes can be distinguished on the leaves:

Non-secretory trichomes straight or hooked, unbranched, with a length of 18-167 $\mu \mathrm{m}$, composed of 1-4 cells (Figs. 2b, c, g, 3j, 4d-f, 5a-e). The basal cells (2-3) of these trichomes are raised above the surface of other epidermis cells.

Long capitate secretory trichomes with a length of $50-62 \mu \mathrm{m}$, formed of a basal cell located within the epidermis, $2-3$ celled stalk and a unicellular, differently shaped (spherical or elongated) glandular head. They are present on the lower surface of the leaves (Fig. 5f-k).

Short capitate secretory trichomes a length of 17-23 $\mu \mathrm{m}$ with a 2-celled head on a 1- or 2-celled stalk and a basal cell with a size similar to that of the other epidermis cells (Figs. 2d, f, 3i, 4f, 5l-p).

Peltate secretory trichomes with a broad head (ca. $75 \mu \mathrm{m}$ in diameter) formed of 8-12 cells and a short stalk composed of 1-2 cells as well as a basal cell with a size similar to that of the other epidermis cells (Figs. 2e, 3g, h, j, 5q-u). 
Fig. 1 Morphology of Dracocephalum moldavica leaves and bracts. a Fragments of plants in the flowering phase, $\mathbf{b}$ fragment of a leaf from the lower part of the plant, $\mathbf{c}$ flowers and bracts from one node on the inflorescence, $\mathbf{d}$ abaxial surface of the bract with visible depressions (arrows) covered by peltate trichomes and e location of peltate trichomes (arrows) on the abaxial surface of the leaf
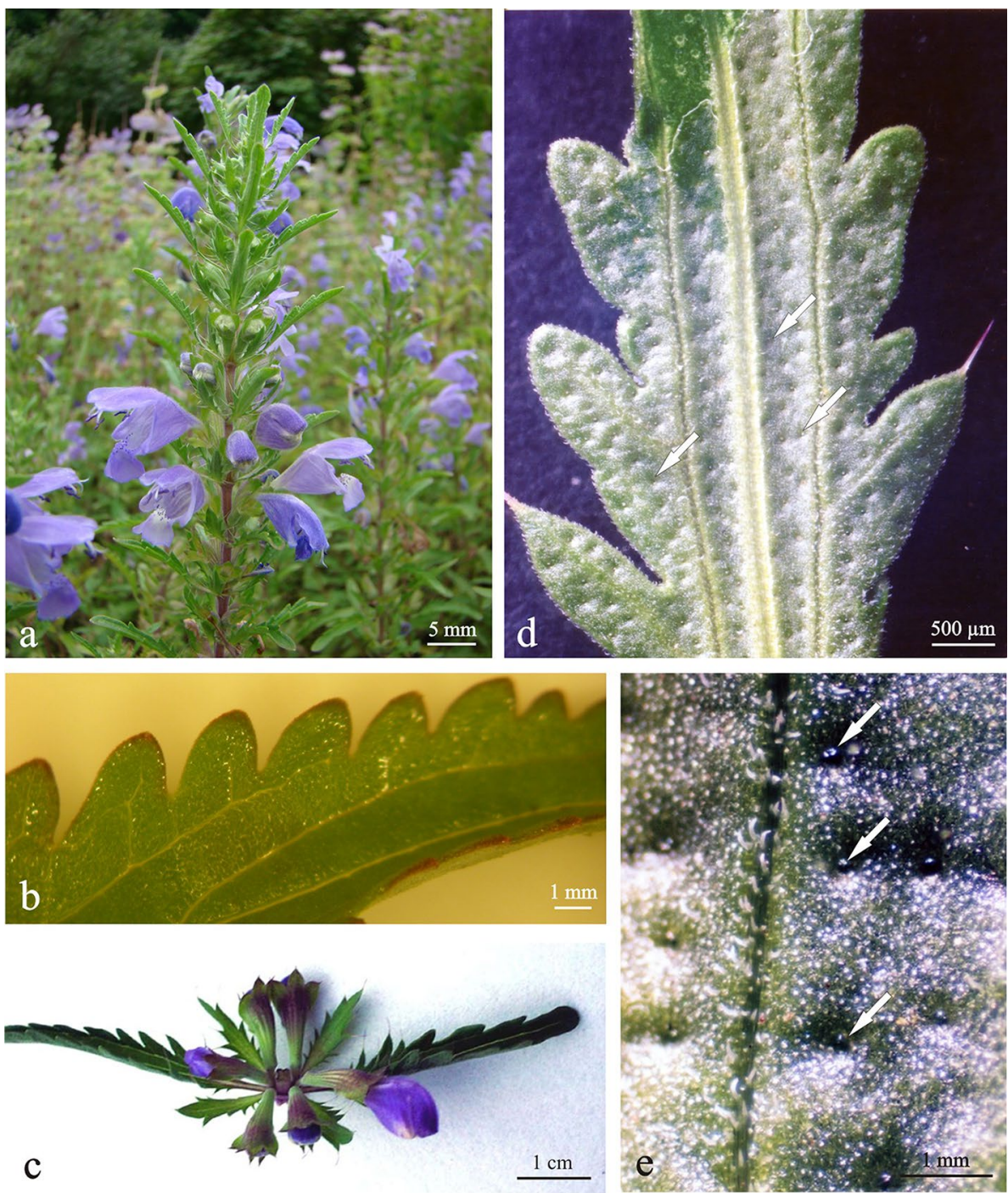

The amphistomatic leaves of the dragonhead are characterised by high density of stomata in both adaxial and abaxial surfaces (Fig. 2b-e, h). Stomatal complexes are located at the same or slightly higher levels than the other epidermis cells (Fig. 2b-e). The stomata are surrounded by a variable number of guard cells (4-6), which is characteristic for the anomocytic type (Fig. 2b-e, h).

Bracts In the inflorescence, six flowers are formed in each node; they grow from the bract axilla, and two of them are larger and four are smaller (Fig. 1c). The teeth on the bract margins differ in shape and size, and some of them have spiky appendages (Fig. 1c, d). The trichomes on both surfaces of the bracts are similarly arranged and have a similar structure to those on the stem leaves. However, we observed that peltate trichomes were more densely arranged on the bracts than on the stem leaves. Their number was $1.5 \cdot \mathrm{mm}^{-2} \pm 0.21$ on the small bracts and $1.8 \cdot \mathrm{mm}^{-2} \pm 0.29$ on the large bracts.
Leaf anatomy - Stem leaves The average thickness of the leaf blade is $282 \pm 51 \mu \mathrm{m}$. The cells of the adaxial epidermis are larger than the cells of the abaxial surface, which is distinctly visible in the leaf cross sections. Noteworthy are the smaller sizes of the stomatal complex cells in comparison with the other epidermis cells (Fig. 3a, b). The cells of the adaxial epidermis exhibit stronger autofluorescence than the cells of the abaxial surface (Fig. 3c-e). The palisade parenchyma in the leaves on the stem is composed of two layers of elongated cells (Fig. 3a, b, g, j). The spongy parenchyma exhibits large intercellular spaces (Fig. 3b).

The vascular bundles are surrounded by a sheath composed of isodiametric parenchyma cells (Fig. 3b). The adaxial part of the leaf blade has depressions above the vascular bundles (Fig. 3a, e). The depressions on the abaxial surface of the leaf blade bear peltate trichomes (Fig. $3 \mathrm{~g}, \mathrm{~h}, \mathrm{j}$ ).

Bracts The bracts are characterised by a lower thickness than the stem leaves. The thickness of the large and small 
Fig. 2 Fragments of the abaxial surface of a $D$. moldavica leaf under scanning electron microscopy. a Non-glandular trichomes located mainly on leaf veins as well as peltate (arrows) and capitate (arrowheads) glandular trichomes present on the intercostal surfaces; $n g t$ non-glandular trichomes, $p t$ peltate trichomes, sct short capitate trichomes, $\mathbf{b}$ fragment of a vein with two non-glandular trichomes and numerous stomatal complexes, $\mathbf{c}$ margin of the leaf blade with numerous hook-like non-glandular trichomes and irregularly arranged stomatal complexes, $\mathbf{d}$ short glandular trichome and dried secretion residue on the surface of epidermis cells, e peltate trichome and numerous stomatal complexes slightly elevated above the surface of other epidermis cells, f short glandular trichome with secretion residue on the surface, g non-glandular trichome with visible ornamentation of the cuticle on the surface of cell wall and $\mathbf{h}$ stomatal complex with guard cells with secretion residue on the surface and four subsidiary cells; $g c$ guard cells, $s c$ subsidiary cells
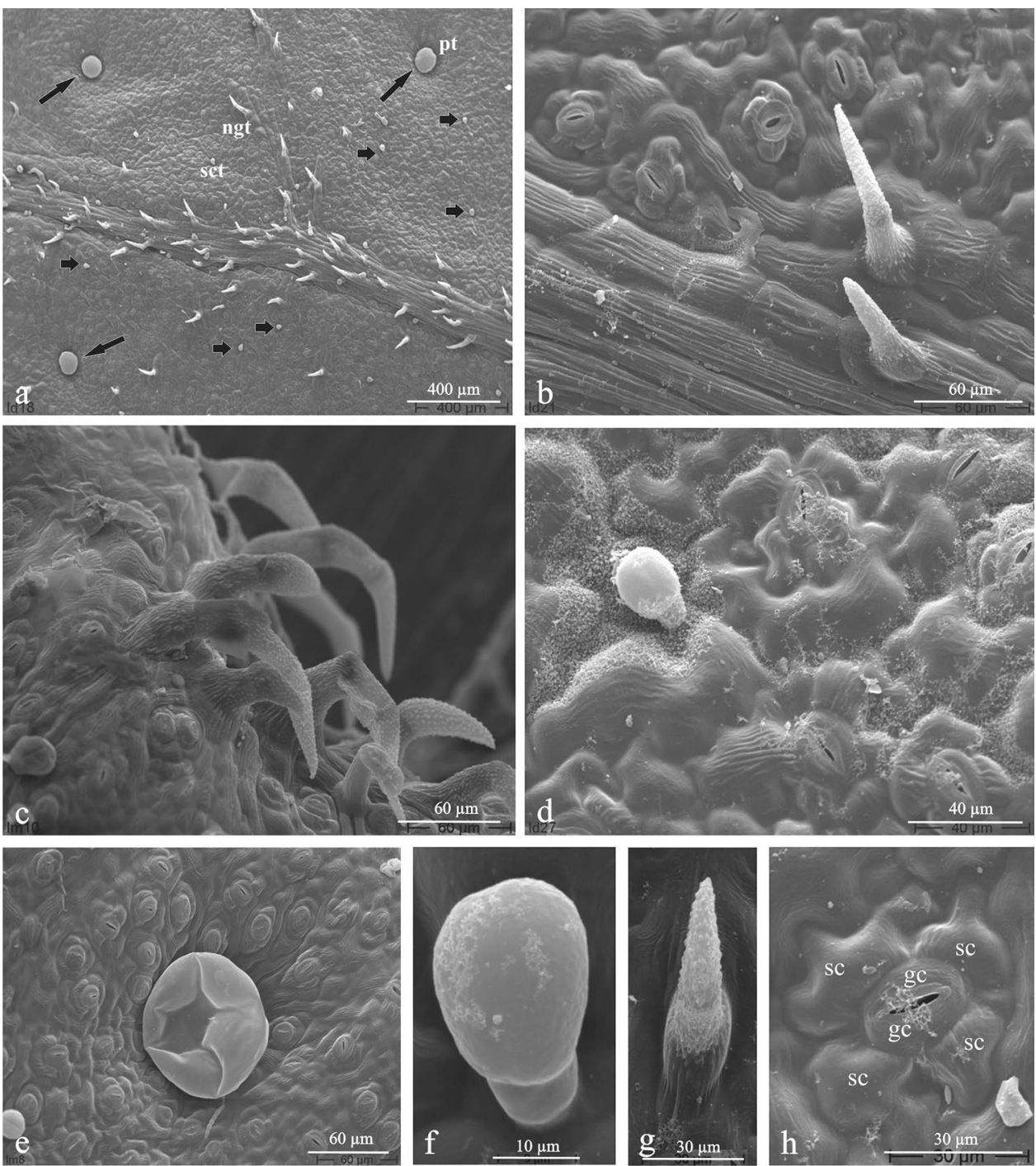

bracts is $237 \pm 40 \mu \mathrm{m}$ and $209 \pm 56 \mu \mathrm{m}$, respectively. The anatomy of the large bracts is similar to that of the stem leaves, and the small bracts are characterised by the presence of undifferentiated mesophyll with loose arrangement of cells and very large distinct intercellular spaces (Fig. 4c).

Histochemical traits of leaf and bract tissues - The histochemical assays and fluorescence microscopy revealed the presence of lipids and various specialised metabolites: phenolic compounds, flavonoids, essential oil, and terpenes in leaf and bract epidermis (Table 1) as well as mesophyll cells and in the different types of trichomes (Table 1). Results of histochemical assays were the same for leaf and bract tissues as well as for their trichomes.

- Epidermis and mesophyll The cross sections stained with methylene blue with azure B exhibited the content of adaxial epidermis and perivascular parenchyma cells, which was clearly darker than the content of other mesophyll cells
(Fig. 3a, b). Fluorescence microscopy revealed the presence of phenolic compounds characterised by light-blue autofluorescence in these tissues and in the abaxial surface (Fig. 3c-e). The presence of phenols in the cells of these tissues was confirmed by the green-blue colour after staining with toluidine blue $\mathrm{O}$ (Fig. 3f, g). Staining with this reagent exhibiting metachromatic properties revealed the presence of pectin compounds in the mesophyll cell walls of the bracts (purple colour) and the content of phenolic compounds in the vacuoles of the trichomes (Fig. 4c) and epidermis cells of the leaves (green-blue colour) (Fig. 3f, g).

The strong light-blue autofluorescence of the content of the subsidiary cells in the stomatal complexes in the leaves is indicative of the presence of phenolic compounds (Fig. 4a, b). We have also demonstrated the presence of flavonoids not only in the some leaf epidermis cells, but also in the basal cells of trichomes, which is indicated by the yellow-green secondary fluorescence of these cells after the treatment with 
Fig. 3 Images of cross sections of $D$. moldavica leaves from the light microscope (a, b, $\mathbf{f}, \mathbf{g}$, j) and fluorescence microscope $(\mathbf{c}-\mathbf{e}, \mathbf{h}, \mathbf{i})$. a, b Leaf tissues stained with methylene blue with visible darker vacuole content in the epidermis cells and perivascular sheath cells (stars). Arrows show stomata, c-e, $\mathbf{h}, \mathbf{i}$ autofluorescence of some tissues in fresh leaf sections: light-blue autofluorescence in epidermis cells and vascular bundles indicates presence of phenolic compounds, and red autofluorescence indicates chlorophyll in mesophyll cells, f, $g$ blue-stained phenolic compounds in epidermis and leaf mesophyll cells (toluidine blue $\mathrm{O}$ ) and $\mathbf{j}$ fragment of the leaf blade stained with Sudan IV: visible orange content of lipids in the different types of trichomes
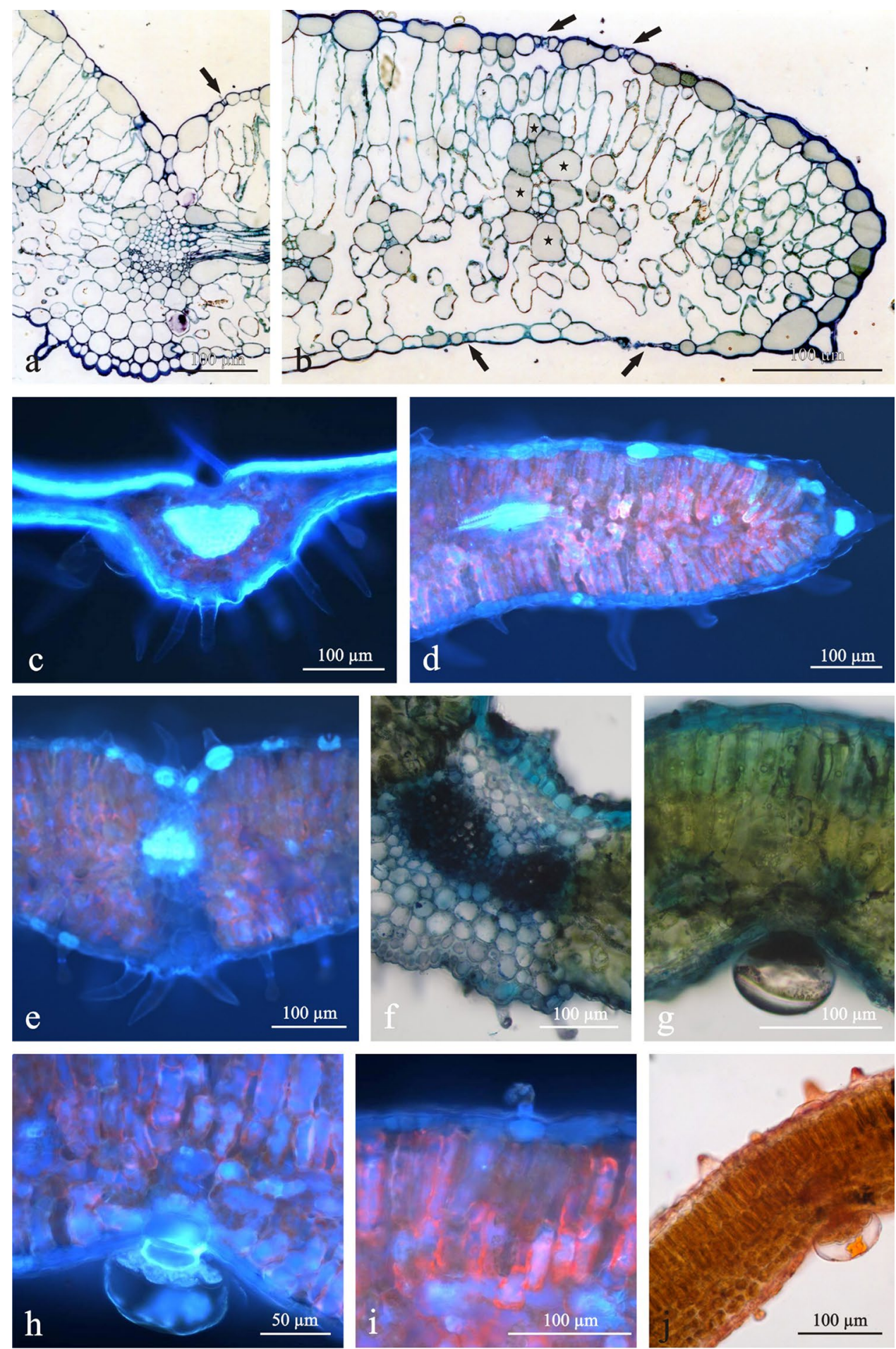

aluminium trichloride (Figs. 4d, 5c, n, s). The application of Sudan IV detected the presence of lipids in some epidermis cells (Fig. 4g-i), especially in the guard cells, while the Nadi reagent indicated the presence of terpenes in these cells (Fig. 4f).

Trichomes Phenolic compounds were detected in all types of trichomes (Figs. 3h, i, 5f, 1, q) as light-blue autofluorescence, which is typical of phenolic acids under ultraviolet light. The presence of phenols in all types of trichomes was confirmed by the toluidine blue $\mathrm{O}$ reagent, which stains these compounds green and blue (Figs. 4a, c, $5 \mathrm{a}, \mathrm{b}, \mathrm{g}-\mathrm{i}, \mathrm{m}, \mathrm{r})$. In non-glandular trichomes, we observed blue staining of trichome cells (Fig. 5a, b). Significant variation of the colour depending on the content of phenolic 

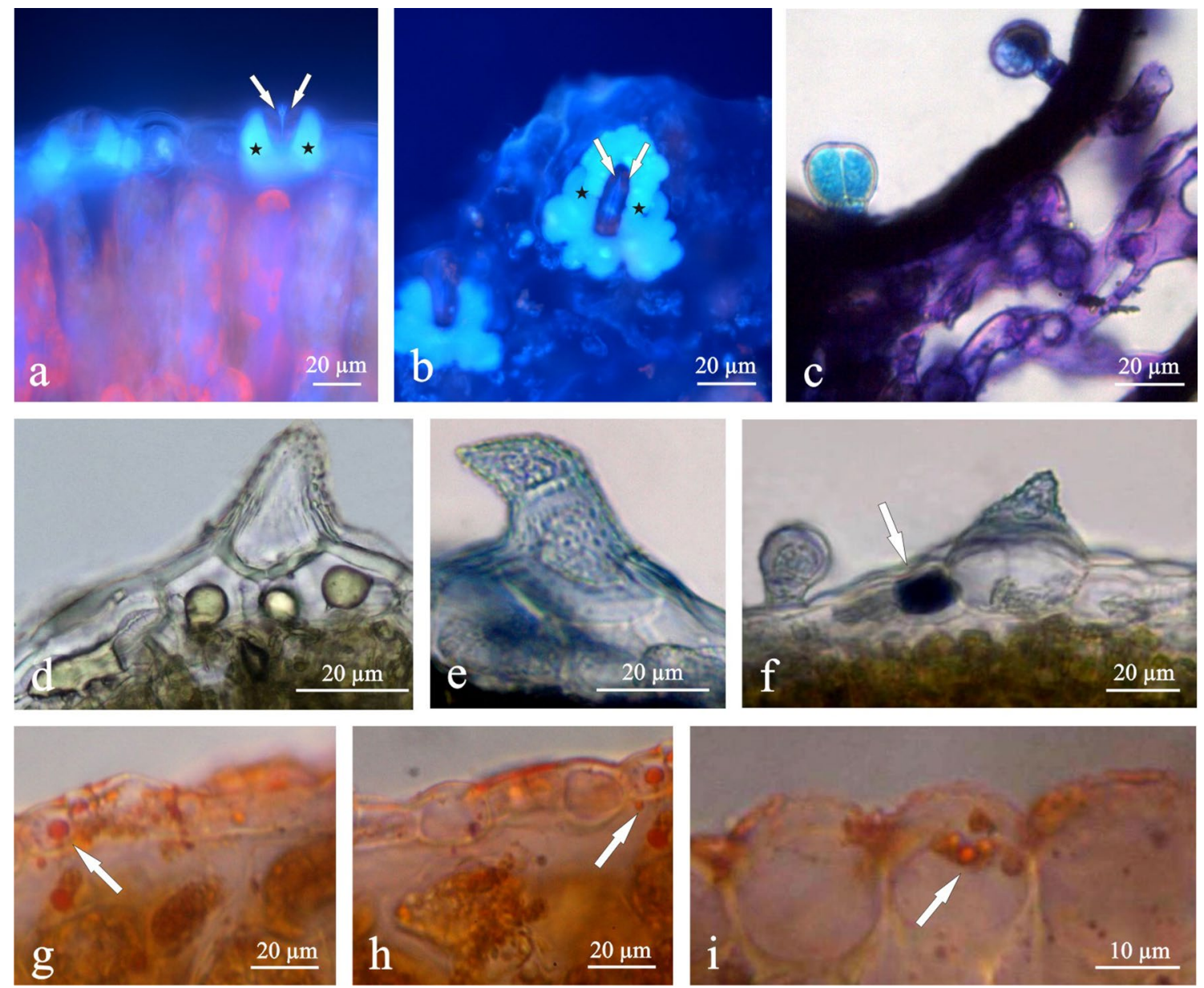

Fig. 4 Fragments of cross sections of leaves and bract and top view of adaxial epidermis cells in fluorescence microscopy (a, b) and after application of different histochemical assays in LM $(\mathbf{c}, \mathbf{d}-\mathbf{i})$. a, b Light-blue autofluorescence of phenolic compounds in the guard cells of stomatal complexes in the leaf. a Cross section, b top view; arrows shows guard cells, asterisks—subsidiary cells, $\mathbf{c}$ spongy parenchyma with pectin content (purple colour) and phenolic compounds (blue colour) in bracts and short capitate trichomes after treatment with toluidine blue O, d flavonoids in the vacuoles of epidermis cells in the leaf, $\mathbf{e}, \mathbf{f}$ terpenes in epidermis cells of leaves and non-glandular trichomes after treatment with Nadi Reagent (blue colour) and $\mathbf{g}-\mathbf{i}$ droplets of lipids (arrows) in leaf epidermis cells treated with Sudan IV

compounds was found in the head and stalk of long capitate trichomes (Fig. 5g-i). These compounds were present in not only the stalks and heads but also the basal cells, which suggests metabolic activity of all parts of the capitate trichomes. Flavonoids were detected after application of aluminium trichloride as a fluorochrome, which induced yellowish secondary fluorescence (Figs. 4d, 5c, j, n, s). In the non-glandular trichomes, flavonoids were detected only in the basal cells (Figs. 4d, 5c). The use of Sudan IV facilitated detection of lipids in the cells of glandular and nonglandular trichomes (orange-red colour) (Figs. 3j, 5d, k, o, $\mathrm{t}, \mathrm{u})$. The presence of terpenes was demonstrated in all types of trichomes after the application of the Nadi reagent, which stained these compounds blue (Figs. 4e, f, 5e, p).
Chemical analysis of essential oil - We have shown in our study that the average content of the essential oil in the dry herb of D. moldavica during flowering was $0.10 \%$. The GC/MS study revealed the presence of 58 compounds, including 55 identified ones (Table 2). Geranial (33.94\%), neral $(32.00 \%)$, geraniol $(9.29 \%)$, nerol $(5.87 \%)$, transmyrtanol acetate $(4.87 \%)$ were the main constituents of the oil. The identified compounds constituted $97.39 \%$ of all the components of the examined oil. Monoterpenes (21) constituting $83.8 \%$ were the main group of compounds. In turn, sesquiterpenes (14) accounted for 3.4\% (Table 2). 

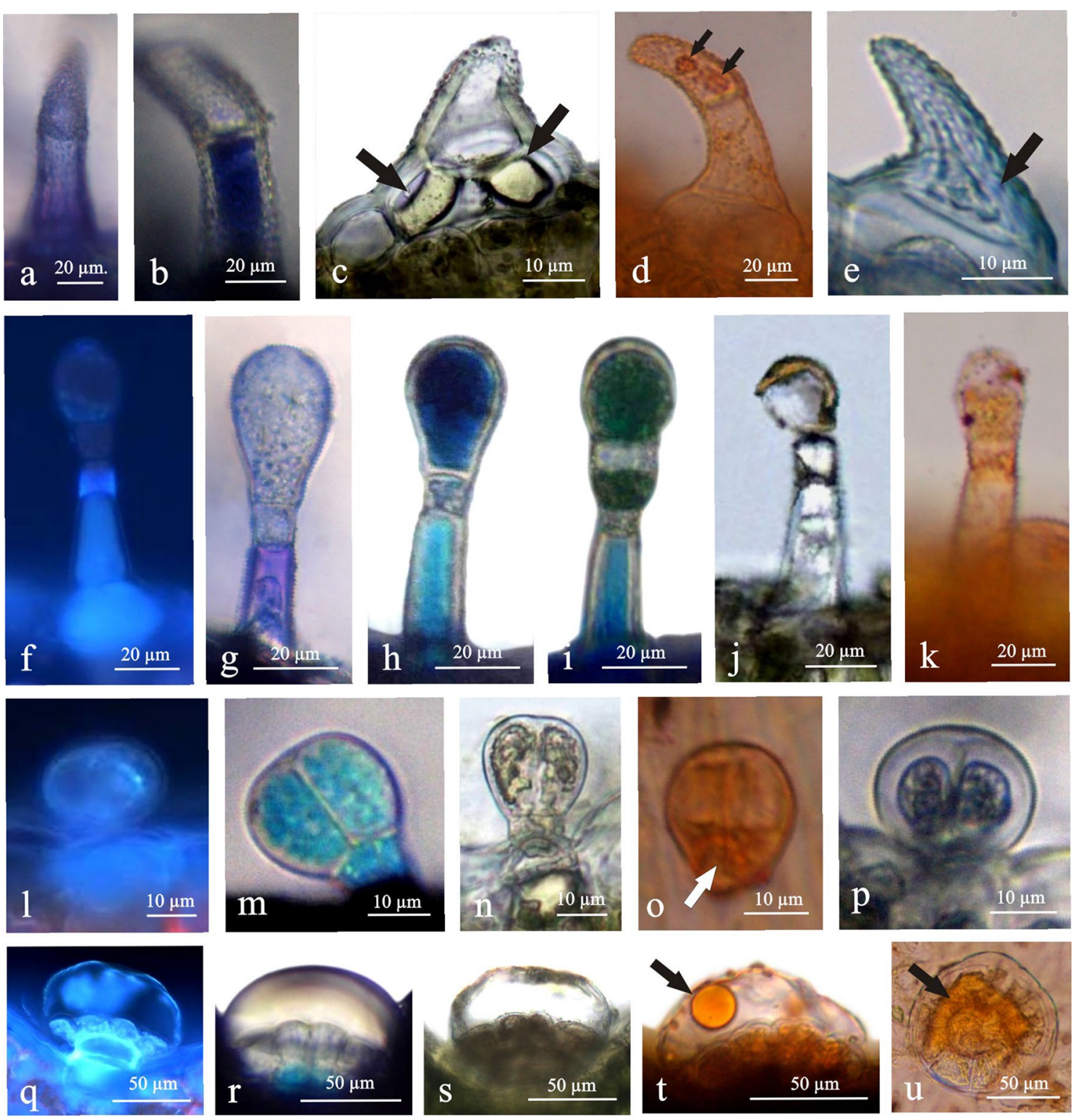

Fig. 5 Histochemical characterisation of the secretions in D. moldavica trichomes. a-e Non-glandular trichomes, $\mathbf{f}-\mathbf{k}$ long capitate secretory trichomes; l-p short capitate secretory trichomes; $\mathbf{q}-\mathbf{u}$ peltate trichomes; $\mathbf{a}, \mathbf{b}$ blue-stained content of the cells (arrows) of non-glandular trichomes after toluidine blue $\mathrm{O}$ treatment, $\mathbf{c}$ yellowish autofluorescence of basal cells content after treatment of $\mathrm{AlCl}_{3}$ (arrows), e blue-stained protoplast and cell wall after Nadi reagent treatment (arrow), $\mathbf{f}$ blue autofluorescence observed in the stalk cells and in the basal cell under UV, $\mathbf{g}-\mathbf{i}$ different cells of trichomes stained blue, violet or green with toluidine blue $\mathrm{O}, \mathbf{j}$ yellowish secondary fluorescence visible in the head cell after treatment with $\mathrm{AlCl}_{3}$ under $\mathrm{Cy}_{5}$ filter, $\mathbf{k}$ content of the head and the stalk cells stained orange with Sudan IV, $\mathbf{l}$ blue autofluorescence in the head cell under $\mathrm{UV}, \mathbf{m}$ green-blue stained the content of the head cells and the stalk cells after toluidine blue $\mathrm{O}, \mathbf{n}$ yellowish fluorescence in the head cells and in the basal cell with $\mathrm{AlCl}_{3}, \mathbf{d}, \mathbf{o}, \mathbf{t}, \mathbf{u}$ trichomes cells content and secretion (arrows) stained orange with Sudan IV, $\mathbf{p}$ content of head cells stained blue with Nadi reagent, $\mathbf{q}$ blue autofluorescence in the glandular and stalk cells under UV, $\mathbf{r}$ content of stalk cells stained blue with toluidine blue $\mathrm{O}$ and $\mathbf{s}$ yellowish content of glandular cells after $\mathrm{AlCl}_{3}$ under $\mathrm{UV}$

\section{Discussion}

As many as $40 \%$ of plants representing 200 genera of the Lamiaceae family are regarded to have aromatic properties. Essential oil from more than 30 selected species has been the object of commerce for more than 75 years (Lawrence 1992). One of the aromatic plants is D. moldavica, whose overground shoots produce essential oil with an intense lemon scent. Our investigations have demonstrated that the aromatic oil is excreted not only by all types of glandular and non-glandular trichomes present on the leaves in this species but also by the leaf epidermis cells. Secretion of essential oils by leaf and stem epidermis cells has been demonstrated in Lavandula as well (Buvat 1989). Konarska (2016) found 
Table 1 Compounds identified in leaf's and bract's epidermis cells and trichomes by histochemical tests and/or fluorescence microscopy

\begin{tabular}{|c|c|c|c|c|c|c|c|}
\hline \multirow[t]{2}{*}{ Test } & \multirow[t]{2}{*}{ Compound } & \multirow[t]{2}{*}{ Colour observed } & \multirow{2}{*}{$\begin{array}{l}\text { Epider- } \\
\text { mis cells }\end{array}$} & \multicolumn{4}{|c|}{ Type of trichomes } \\
\hline & & & & $\begin{array}{l}\text { Non- } \\
\text { glandular }\end{array}$ & Peltate & Long capitate & Short capitate \\
\hline \multirow[t]{2}{*}{ Toluidine blue $\mathrm{O}$} & Phenolic compounds, & Green, blue & + & + & + & + & + \\
\hline & Pectins & Violet & - & + & - & + & - \\
\hline Aluminium trichloride (UV) & Flavonoids & Yellow-greenish & + & + & + & + & + \\
\hline Sudan IV & Lipids & Orange & + & + & + & + & + \\
\hline Nadi reagent & Terpenes & Violet-blue & + & + & + & + & + \\
\hline Autofluorescence & Phenolic compounds & Light blue & + & - & + & + & + \\
\hline
\end{tabular}

the drops of essential oil in the epidermis cells of the bracts of Viburnum lantana L. (Adoxaceae).

Secretory epidermis producing terpenes is usually located on the petals of various flowers: Rosa L. (Caissard et al. 2006; Bergougnoux et al. 2007; Sulborska et al. 2012), Viola tricolor L. (Whitney et al. 2009), Viola $\times$ wittrockiana Gams. (Weryszko-Chmielewska and Sulborska 2012), Syringa and Jasminum (Buvat 1989), and Galanthus nivalis L. (Weryszko-Chmielewska and Chwil 2016). In petal epidermis of some Lamiaceae representatives (Dracocephalum moldavica and Lamium album L.) there were found papillae, which probably secrete essential oils (Dmitruk and WeryszkoChmielewska 2010; Sulborska et al. 2014). Buvat (1989) has found that secretory epidermis in most cases produces essential oils. In the present study, we detected lipids and terpenes in leaf epidermis cells. In aromatic and scented plants, volatile organic compounds originate from three categories of chemicals: phenolic compounds, fatty acid derivatives, and terpenes (Caissard et al. 2004).

In the present study, we have extended our previous analyses of exogenous secretory tissues in $D$. moldavica (Dmitruk and Weryszko-Chmielewska 2010) to include all leaf tissues and employed analyses facilitating localisation of specialised metabolites.

The histochemical assays and fluorescence microscopy applied to the epidermis cells of D. moldavica leaves and all morphotypes of trichomes revealed the presence of the categories of chemicals mentioned above, which confirms the production and emission of essential oils by these structures. There were lipids, terpenes, and phenolic compounds, including flavonoids, in all the types of trichomes. Therefore, they can be regarded as glandular trichomes secreting lipophilic substances. Terpenes are the most commonly occurring lipophilic substances in glandular trichomes. They serve many functions in plants, e.g. they can be herbivore deterrents (Simmonds and Blaney 1992; Chwil et al. 2016) and pollinator attractants (Evert 2006; Chizzola 2013); flowers of D. moldavica are visited by different Apidae: Apis mellifera L., Bombus sp., wild bees, and Lepidoptera (Ruszkowski et al. 1997; Jabłoński 1998; Lipiński 2010). Terpenes also exhibit antioxidant, antiviral, anti-bacterial, and anti-fungal activity (Dorman and Deans 2000a, b; Abdellatif et al. 2014; Tantry et al. 2014).

Non-glandular trichomes are most often regarded as common, mechanical, clothing, or tector trichomes (Metcalfe and Chalk 1972; Evert 2006; Hejnowicz 2018). In this type of trichomes, we have detected phenolic compounds, lipids, essential oils, and terpenes, and the basal cells of these trichomes contained flavonoids. The results of our investigations are in agreement with the reports by Combrinck et al. (2007), who demonstrated a secretory nature in seta-type non-glandular trichomes in Lippia scaberrima Sond. (Verbenaceae). The authors of this study detected specialised metabolites in the basal region of these trichomes. Similarly, flavonoids were detected in the basal part of non-glandular stellate and dendritic trichomes in Cistus salvifolius L. (Tattini et al. 2007), as well as in trichomes located on the upper surface of the palate of Linaria vulgaris (L.) Mill. (Plantaginaceae) (Jachuła et al. 2018). Tozin et al. (2016) observed that non-glandular trichomes in three species from the family Lamiaceae and in four species from the family Verbenaceae produced, accumulated, and released bioactive compounds. The authors mentioned above suggest that the non-glandular trichomes with secretory activity in the analysed species can be involved in the chemical interactions between plants and the environment.

Production of phenolic compounds in leaf epidermis cells has been detected in only few plant species. In the present study, we have demonstrated their presence in the epidermis cells of $D$. moldavica leaves. Phenolic idioblasts were detected earlier in the epidermis of Kalanchoë crenata (Andrews) Haw. (Moreira et al. 2012) and Kalanchoë daigremontiana Raym.-Hamet and H. Perrier leaves (Chernetskyy et al. 2018).

Leaf mesophyll layers and perivascular sheaths are a common location of phenolic idioblasts, which has been demonstrated in this paper in the D. moldavica leaves. Previous studies showed the presence of phenolic-producing cells located in the mesophyll of Inula viscosa (L.) Aiton leaves (Nikolakaki and Christodoulakis 2004) as well as 
Table 2 Chemical composition of herb essential oil of Dracocephalum moldavica harvested in generative stage

\begin{tabular}{|c|c|c|c|c|c|}
\hline No. & Compound & $\mathrm{RT}^{\mathrm{a}}(\min )$ & $\mathrm{RRI}^{\mathrm{a}}$ & $\mathrm{AI}^{\mathrm{b}}$ & $\%$ \\
\hline \multicolumn{6}{|c|}{ Monoterpenes } \\
\hline 1. & Myrcene & 8.200 & 989 & 988 & 0.18 \\
\hline 2. & $\alpha$-Terpinene & 9.112 & 1015 & 1014 & $\operatorname{tr}$ \\
\hline 3. & Limonene & 9.531 & 1026 & 1024 & 0.07 \\
\hline 4. & $\beta$-Phellandrene & 9.582 & 1028 & 1025 & $\operatorname{tr}$ \\
\hline 5. & (Z)- $\beta$-ocimene & 9.756 & 1032 & 1032 & 0.08 \\
\hline 6. & E- $\beta$-ocimene & 10.115 & 1042 & 1044 & 0.23 \\
\hline 7. & $\gamma$-Terpinene & 11.477 & 1077 & 1054 & $\operatorname{tr}$ \\
\hline 8. & Linalool & 11.983 & 1090 & 1095 & 0.27 \\
\hline 9. & $\alpha$-Pinene oxide & 12.196 & 1096 & 1099 & 0.17 \\
\hline 10. & trans-Thujone & 13.356 & 1132 & 1112 & 0.17 \\
\hline 11. & $\beta$-Pinene oxide & 13.728 & 1144 & 1154 & 0.70 \\
\hline 12. & Nerol oxide & 13.827 & 1147 & 1154 & 0.11 \\
\hline 13. & Neoiso menthol & 14.481 & 1168 & 1184 & 0.06 \\
\hline 14. & $\alpha$-Terpineol & 15.374 & 1196 & 1186 & 0.14 \\
\hline 15. & Dihydrocarveol & 15.772 & 1208 & 1192 & 0.47 \\
\hline 16. & trans-Carveol & 16.143 & 1219 & 1215 & 0.07 \\
\hline 17. & Nerol & 16.418 & 1228 & 1227 & 5.87 \\
\hline 18. & Neral & 16.986 & 1244 & 1235 & 32.00 \\
\hline 19. & Geraniol & 17.349 & 1255 & 1249 & 9.29 \\
\hline 20. & Geranial & 18.032 & 1275 & 1264 & 33.94 \\
\hline 21 & 3-Thujyl acetate & 18.835 & 1299 & 1295 & $\operatorname{tr}$ \\
\hline \multicolumn{6}{|c|}{ Sesquiterpenes } \\
\hline 1. & $\alpha$-Copaene & 21.472 & 1377 & 1374 & 0.25 \\
\hline 2. & $\beta$-Bourbonene & 21.751 & 1385 & 1387 & 0.22 \\
\hline 3. & $\beta$-Elemene & 21.922 & 1390 & 1387 & 0.14 \\
\hline 4. & E-Caryophyllene & 22.895 & 1423 & 1417 & 0.46 \\
\hline 5. & $\beta$-Copaene & 23.221 & 1435 & 1430 & tr. \\
\hline 6. & $\alpha$-Humulene & 24.028 & 1465 & 1452 & 0.07 \\
\hline 7. & D-germacrene & 24.829 & 1494 & 1484 & 1.49 \\
\hline 8. & Bicyclogermacrene & 25.287 & 1508 & 1500 & 0.24 \\
\hline 9. & (EE) $\alpha$-Farnesene & 25.537 & 1516 & 1505 & 0.18 \\
\hline 10. & A germacrene & 25.641 & 1519 & 1508 & $\operatorname{tr}$ \\
\hline 11. & $\gamma$-Cadinene & 25.820 & 1524 & 1513 & $\operatorname{tr}$ \\
\hline 12. & $\delta$-Cadinene & 25.975 & 1529 & 1522 & 0.16 \\
\hline 13. & Caryophyllene oxide & 27.893 & 1586 & 1582 & 0.23 \\
\hline 14. & Humulene epoxide II & 28.715 & 1614 & 1608 & $\operatorname{tr}$ \\
\hline \multicolumn{6}{|c|}{ Aldehydes, ketones } \\
\hline 1. & 6-Methyl-5-hepten-2-one & 8.066 & 985 & 981 & 0.43 \\
\hline 2. & o-cymene & 9.373 & 1022 & 1022 & 0.06 \\
\hline 3. & Bergamal & 11.396 & 1075 & 1051 & $\operatorname{tr}$ \\
\hline 4. & 2 E-decenal & 17.723 & 1266 & 1260 & 0.06 \\
\hline \multicolumn{6}{|c|}{ Alcohols } \\
\hline 1. & (3Z)Hexenol & 4.489 & 871 & 850 & $\operatorname{tr}$ \\
\hline 2. & 1-Octen-3-ol & 7.911 & 980 & 972 & 0.13 \\
\hline 3. & Octanol-3 & 8.459 & 998 & 994 & 0.05 \\
\hline 4. & trans-Verbenol & 13.529 & 1137 & 1140 & 0.61 \\
\hline 5. & cis-Chrysanthenol & 14.173 & 1158 & 1160 & 1.50 \\
\hline 6. & Lavandulol & 14.684 & 1174 & 1165 & 0.22 \\
\hline 7. & Sphatulenol & 27.727 & 1581 & 1577 & 0.15 \\
\hline 8. & Globulol & 27.989 & 1589 & 1590 & $\operatorname{tr}$ \\
\hline
\end{tabular}


Table 2 (continued)

\begin{tabular}{llllll}
\hline No. & Compound & $\mathrm{RT}^{\mathrm{a}}(\mathrm{min})$ & $\mathrm{RRI}^{\mathrm{a}}$ & $\mathrm{AI}^{\mathrm{b}}$ & $\%$ \\
\hline 9. & 1,10 di-epi-Cubenol & 28.866 & 1621 & 1618 & 0.17 \\
10. & Neo-intermedeol & 29.999 & 1667 & 1658 & 0.08 \\
Esters & & & & & \\
1. & Methyl geranate & 19.691 & 1324 & 1322 & 0.39 \\
2. & Neryl acetate & 20.920 & 1361 & 1359 & 1.41 \\
3. & trans-Myrtanol acetate & 21.573 & 1380 & 1385 & 4.87 \\
Epoxides & & & & & \\
1. & Epoxy-allo-alloaromadendrene & 29.373 & 1641 & 1639 & $\mathrm{tr}$ \\
Sulphides & Mint sulphide & & & & \\
1. & & 32.298 & 1749 & 1740 & $\mathrm{tr}$ \\
Dienes & cis-Muurola 4(14), 5-diene & 24.233 & 1472 & 1465 & $\mathrm{tr}$ \\
1. & & & & & \\
Non-identified & n.i. & 14.840 & 1179 & & 2.05 \\
& n.i. & 18.585 & 1292 & & 0.08 \\
& n.i. & 26.330 & 1539 & & 0.10 \\
& & & & & Total 99.62\% \\
\hline
\end{tabular}

$n . i$. non-identified, $R T$ retention time, $R R I$ relative retention index, $A I$ arithmetic index on DB-5 in reference to $n$-alkanes, $\operatorname{tr}$ trace $(<0.05 \%)$

${ }^{\mathrm{a}}$ Van Den Dool and Kratz (1963)

${ }^{\mathrm{b}}$ Adams (2007)

Crassula multicava Lem. (Castro and Demarco 2008) and several Kalanchoë species (Leal-Costa et al. 2010; Moreira et al. 2012; Chernetskyy et al. 2018).

Different classes of phenolic compounds serve different functions. Phenols provide chemical defence against pathogens and exhibit antimicrobial activity (Castro and Demarco 2008). Tannins exert a deterrent effect on herbivores by impeding digestion in their organisms and exhibit antioxidant activity (Taiz and Zeiger 2002; Blazics and Kéry 2007). Flavonoids protect plants against UV radiationinduced damage (Castro and Demarco 2008) and pathogens (Harborne 1997). They have antioxidant properties (Zhang et al. 2011) and help insects to localise pollen, nectar, and oil in flowers (Yoshitama 2000).

A characteristic feature of the family Lamiaceae is the simultaneous occurrence of diverse types of non-glandular and glandular trichomes (Metcalfe and Chalk 1972; Evert 2006). The most typical for this family are peltate trichomes, which are defined as short-stalked glands with a broad head composed of 4 to 18 secretory cells arranged in a single layer (Evert 2006). In D. moldavica, peltate trichomes with an 8-12-celled head were present only on the lower surface of the leaf blades. Their number per unit area on the bracts was by $60 \%$ greater than on the leaves collected from the middle part of the stem.

Besides peltate trichomes, the analysed species had two types of capitate trichomes: short-stalked and longstalked, which is characteristic for most Lamiaceae species
(Bosabalidis 2002; Evert 2006). The short-stalked trichomes in D. moldavica were characterised by a bicellular head, which is typical of only some Lamiaceae species (Metcalfe and Chalk 1972). This type of capitate trichomes was also observed, e.g. in Marrubium vulgare L. (Haratym and Weryszko-Chmielewska 2017), Melissa officinalis L. (Schultze et al. 1992; Chwil et al. 2016), different Salvia species (Serrato-Valenti et al. 1997; Bisio et al. 1999), and Isodon rubescens (Hemsl.) H. Hara (Liu and Liu 2012).

The long-stalked glandular trichomes in D. moldavica have a unicellular head and a stalk with $2-3$ cells. As in our previous series of studies (Dmitruk and WeryszkoChmielewska 2010), we have found high morphological diversity of cells building the head of these trichomes. Such trichomes have also been described in Isodon rubescens (Liu and Liu 2012), Salvia aegyptica L. (Janošević et al. 2016), and Marrubium vulgare (Haratym and WeryszkoChmielewska 2017). The non-glandular trichomes in $D$. moldavica were uniseriate, uni- or multicellular (1-4 cells), erect or curved, and commonly with swollen basal cells. We showed the characteristic sculpture of the trichome surface in our previous work (Dmitruk and Weryszko-Chmielewska 2010).

The characteristic traits of the anatomy of $D$. moldavica leaves include the considerable thickness (209-282 $\mu \mathrm{m})$ and the presence of stomatal complexes on both surfaces of leaf blades. The stomatal complexes represent the anomocytic type, in contrast to the reports by Metcalfe and Chalk (1972) 
and Evert (2006), who classify stomata in the Lamiaceae family into the Dianthus-diacytic type.

The present investigations indicate that the $D . \mathrm{mol}$ davica herb produces a relatively small amount of a complex mixture of volatile substances $(0.10 \%)$ in the beginning of September during the flowering period. A higher level of oil $(0.15 \%)$ in $D$. moldavica herb was reported by Shuge et al. (2009). Much higher content of oil was demonstrated by Nikitina et al. (2008) and Kakasy et al. (2002), i.e. $0.30-0.35 \%$ and $0.40-0.83 \%$, respectively. It has been underlined in a previous study that qualitative and quantitative results largely depend on the physical and chemical conditions of plants (Schultze et al. 1992).

The composition of essential oil and its quantitative content depend on the stage of plant growth and the plant part used to extract the oil (Gorra and Lis 2005). The traits of essential oil also depend on climatic conditions, location in a geographical zone, and agrotechnology used for plant cultivation (Nikitina et al. 2008).

We have demonstrated in the present study that monoterpenes, geranial (citral a), and neral (citral b) are the main components of the D. moldavica essential oil. Other researchers have also identified these monoterpenes as the major constituents of the essential oil in this species (Kakasy et al. 2002; Nikitina et al. 2008, Shuge et al. 2009). Also geraniol, which was detected in this species by Kakasy et al. (2002), Nikitina et al. (2008) and Fallah et al. (2018), and nerol, which was mentioned by Nikitina et al. (2008) and Fallah et al. (2018), account for a significant proportion in the examined in our study essential oil.

Since D. moldavica herb has been used as a Melissa officinalis adulterant in therapy, we compared the composition of the essential oils in both these species. The essential oil from the M. officinalis herb was also dominated by geranial and neral (Schultze et al. 1992; Nurzynska-Wierdak et al. 2014). Caryophyllene $\mathrm{E}$ and linalool detected by us in the $D$. moldavica oil have been found in the oil from M. officinalis herb by Nurzynska-Wierdak et al. (2014). Furthermore, the content of essential oil extracted from M. officinalis herb, i.e. $0.1-0.3 \%$ (Góra and Lis 2005), is similar to some of the values mentioned above for $D$. moldavica.

The comparison of the anatomical traits of $D$. moldavica leaves determined in this study and $M$. officinalis presented in the study by Chwil et al. (2016) revealed a number of differences. The stomata are present on both sides of the leaves in D. moldavica and only on the abaxial surface in $M$. officinalis. M. officinalis leaves bear protective trichomes on both adaxial and abaxial surfaces, whereas in $D$. moldavica they are located at leaf margins and on the abaxial surface. Greater morphological differentiation of glandular trichomes was demonstrated in M. officinalis than in D. moldavica. Digitiform trichomes and capitate trichomes composed of a 1-celled stalk and a 1-, 3-, and 4-celled head were only detected in M. officinalis (Chwil et al. 2016). However, a characteristic feature of $D$. moldavica leaves that has not been described in other Lamiaceae representatives so far is the production and secretion of essential oil containing terpenes and phenolic compounds by epidermis cells.

To sum up, it can be concluded that our study has shown involvement of not only glandular trichomes but also nonglandular trichomes and leaf epidermis cells in the production and secretion of the scent of dragonhead leaves. Lipids, terpenes, phenolic compounds, and flavonoids were detected in these cells with the use of histochemical assays and fluorescence microscopy. Phenolic compounds were clearly visible in the subsidiary cells of the stomatal complexes and were additionally determined in the leaf mesophyll and perivascular sheaths. These cells contain phenolic compounds as well, which we have shown for the first time for the species of Lamiaceae family.

The intense odour of these plants is emitted by their leaves, as well as flowers and stems what was reported earlier by Dmitruk and Weryszko-Chmielewska (2010), since secretory trichomes are located on those organs. The secretory activity of different morphotypes of trichomes and common epidermis cells contributes to production of substantial amounts of essential oil in the plant $(0.10 \%)$.

D. moldavica applied earlier in medicine as an adulterant of Melissa officinalis exhibits differences in the leaf anatomy in terms of the morphotypes and distribution of trichomes and stomata. In turn, the essential oil contains differing levels of the same dominant components.

Acknowledgements The authors thank the anonymous Reviewers and the Editors for careful reviewing this manuscript. The research was supported financially by Poland's Ministry of Science and Higher Education as part of the statutory activities (project OKB/DS/8) of the Department of Botany and Plant Physiology, University of Life Sciences in Lublin.

Author's contributions The following declarations about authors' contributions to the research have been made: idea of the study: EWC; microscopical analysis: MD, AS, BŻ, ES, EWC; chemical analysis: BŻ, AS; photographs: ES, MD, AS; writing of the manuscript: EWC, $\mathrm{MD}, \mathrm{AS}, \mathrm{BZZ}, \mathrm{ES}$.

Open Access This article is distributed under the terms of the Creative Commons Attribution 4.0 International License (http://creativeco mmons.org/licenses/by/4.0/), which permits unrestricted use, distribution, and reproduction in any medium, provided you give appropriate credit to the original author(s) and the source, provide a link to the Creative Commons license, and indicate if changes were made.

\section{References}

Abdellatif F, Boudjella H, Zitouni A, Hassani A (2014) Chemical composition and antimicrobial activity of the essential oil from leaves of Algerian Melissa officinalis L. EXCLI J 13:772-781 
Adams RP (2001) Identification of essential oil components by gas chromatography/quadrupole mass spectroscopy, 3rd edn. Allured Publishing Corporation, Carol Stream

Adams RP (2007) Identification of essential oil components by gas chromatography/mass spectroscopy, 4th edn. Allured Publishing Corporation, Carol Stream

Amin G (1991) Popular medicinal plants of Iran, vol 1. Deputy of Research, Ministry of Health and Educational Medicine, Tehran

Aprotosoaie AC, Mihai CT, Vochita G, Rotinberg P, Trifan A, Luca SV, Petreus T, Gille E, Miron A (2016) Antigenotoxic and antioxidant activities of a polyphenolic extract from European $\mathrm{Dra}$ cocephalum moldavica L. Ind Crop Prod 79:248-257. https:// doi.org/10.1016/j.indcrop.2015.11.004

Ascensão L, Marques NE, Castro MM (1995) Glandular trichomes on vegetative and reproductive organs of Leonotis leonurus (Lamiaceae). Ann Bot 75:619-626

Baker JR (1966) Cytological technique-the principles underlying routine methods, 5th edn. Menthuen \& Co Ltd, London

Bergougnoux V, Caissard JC, Jullien F, Magnard JL, Scalliet G, Cock JM (2007) Both the adaxial and abaxial epidermis layers of the rose petal emit volatile scent compounds. Planta 226:853-866. https://doi.org/10.1007/s00425-007-0531-1

Bisio A, Corallo A, Gastaldo P, Romussi G, Ciarallo G, Fontana N, de Tommasi N, Profumo P (1999) Glandular hairs in Salvia blepharophylla Brandegee ex Epling grown in Italy. Ann Bot 83:441-452. https://doi.org/10.1006/anbo.1998.0838

Blazics B, Kéry Á (2007) Antioxidant activity of compounds in Euphrasia officinalis L.—revaluation of a traditional medicinal plant. Planta Med 73:266. https://doi.org/10.1055/s-2007-98704 7

Bosabalidis AM (2002) Structural features of Origanum sp. In: Kintzios SE (ed) Oregano: The genera Origanum and Lippia. Taylor and Francis, London, pp 11-64

Brickell Ch (1999) Dracocephalum. Wielka Encyklopedia Roślin Ogrodowych od A do Z. Muza SA, Warszawa

Burt S (2004) Essential oils: their antibacterial properties and potential applications in foods - a review. Int J Food Microbiol 94:223-253. https://doi.org/10.1016/j.ijfoodmicro.2004.03.022

Buvat R (1989) Secretory cells and secretory tissues. In: Buvat R (ed) Ontogeny, cell differentiation, and structure of vascular plants. Springer, Berlin, pp 482-502

Caissard J-C, Joly C, Bergougnox V, Hugueney P, Mauriat M, Baudino $S$ (2004) Secretion mechanisms of volatile organic compounds in specialized cells of aromatic plants. Rec Res Develop Cell Biol $2: 1-15$

Caissard J-C, Bergougnoux V, Martin M, Mauriat M, Baudino S (2006) Chemical and histochemical analysis of 'Quatre Saisons Blanc Mousseux' a moss rose of the Rosa $\times$ damascena group. Ann Bot 97:231-238

Castro MM, Demarco D (2008) Phenolic compounds produced by secretory structures in plants: a brief review. Nat Prod Commun 3:1273-1284

Charrière-Ladreix Y (1973) Répartition intracellulaire du secrétat flavonique de Populus nigra L. Planta 129:167-174

Chernetskyy M, Woźniak A, Skalska-Kamińska A, Żuraw B, Blicharska E, Rejdak R, Donica H, Weryszko-Chmielewska E (2018) Structure of leaves and phenolic acids in Kalanchoë daigremontiana Raym.-Hamet \& H. Perrier. Acta Sci Pol Hortorum Cultus 17:137-155. https://doi.org/10.24326/asphc.2018.4.13

Chizzola R (2013) Regular monoterpenes and sesquiterpenes (essential oils). In: Ramawat KG, Mérillon JM (eds) Natural products. Springer, Berlin, pp 2973-3008

Chwil M, Nurzyńska-Wierdak R, Chwil S, Matraszek R, Neugebauerová J (2016) Histochemistry and micromorphological diversity of glandular trichomes in Melissa officinalis L. leaf epidermis. Acta Sci Pol Hortorum Cultus 15:153-172
Combrinck S, Plooy GW, McCrindle RI, Botha BM (2007) Morphology and histochemistry of glandular trichomes of Lippia scaberrima (Verbenaceae). Ann Bot 99:1111-1119. https://doi. org/10.1093/aob/mcm064

Corsi G, Bottega S (1999) Glandular hairs of Salvia officinalis: new data on morphology, localization and histochemistry in relation to function. Ann Bot 84:657-664. https://doi.org/10.1006/ anbo.1999.0961

Dastmalchi K, Dorman HJD, Laakso I, Hiltunen R (2007) Chemical composition and antioxidative activity of Moldavian balm ( $\mathrm{rra}-$ cocephalum moldavica L.) extracts. Food Sci Technol 40:16551663. https://doi.org/10.1016/j.lwt.2006.11.013

David R, Carde JP (1964) Coloration différentielle des inclusions lipidique et terpéniques des pseudophylles du pin maritime au moyen du réactif Nadi. C R Acad Sci Paris 258:1338-1340

Dmitruk M, Weryszko-Chmielewska E (2010) Morphological differentiation and distribution of non-glandular and glandular trichomes on Dracocephalum moldavicum L. shoots. Acta Agrobot 63:11-22

Dmitruk M, Weryszko-Chmielewska E, Sulborska A (2018) Flowering and nectar secretion in two forms of the moldavian dragonhead (Dracocephalum moldavica L.) — a plant with extraordinary apicultural potential. J Apic Sci 62:97-109. https://doi.org/10.2478/ jas-2018-0010

Dorman HJD, Deans SG (2000a) Antimicrobial agents from plants: antibacterial activity of plant volatile oils. J Appl Microbiol 88:308-316. https://doi.org/10.1046/j.1365-2672.2000.00969.x

Dorman HJD, Deans SG (2000b) Antimicrobial agents from plants: antibacterial activity of plant volatile oils. J Appl Microbiol 88:308-316. https://doi.org/10.1046/j.1365-2672.2000.00969.x

Duke SO (1994) Glandular trichomes - a focal point of chemical and structural interactions. Int J Plant Sci 155:617-620. https://doi. org/10.1086/297200

Evert RF (2006) Esau's plant anatomy, 3rd edn. Wiley, Hoboken

Farmakopea Polska VIII. Urząd Rejestracji Produktów Leczniczych, Warszawa

Fallah S, Rostaei M, Lorigooini Z, Surk AA (2018) Chemical compositions of essential oil and antioxidant activity of dragonhead (Dracocephalum moldavica) in sole crop and dragonhead-soybean (Glycine max) intercropping system under organic manure and chemical fertilizers. Ind Crop Prod 115:158-165. https://doi. org/10.1016/j.indcrop.2018.02.003

Gahan B (1984) Plant histochemistry and cytochemistry: an introduction. Academic Press, London

Góra J, Lis A (2005) Najcenniejsze olejki eteryczne. Wydawnictwo Naukowe Uniwersytetu Mikołaja Kopernika, Toruń

Haratym W, Weryszko-Chmielewska E (2017) Ultrastructural and histochemical analysis of glandular trichomes of Marrubium vulgare L. (Lamiaceae). Flora 231:11-20. https://doi.org/10.1016/j.flora .2017.04.001

Harborne JB (1997) Ekologia biochemiczna. Wyd. Naukowe PWN, Warszawa

Hegi G (1965) Illustrierte Flora von Mittel-Europa. V(4). Verlag, Carl Hanser, München

Hejnowicz Z (2018) Anatomia i histogeneza roślin naczyniowych. Wydawnictwo Naukowe PWN, Warszawa

Jabłoński B (1998) Wiadomości z botaniki pszczelarskiej. In: Prabucki J (ed) Pszczelnictwo. Wyd Promocyjne "Albatros", Szczecin

Jachuła J, Konarska A, Denisow B (2018) Micromorphological and histochemical attributes of flowers and floral reward in Linaria vulgaris (Plantaginaceae). Protoplasma. https://doi.org/10.1007/ s00709-018-1269-2

Janošević D, Budimir S, Alimpić A, Marin P, Al Sheef N, Giweli A, Duletić-Laušević S (2016) Micromorphology and histochemistry of leaf trichomes of Salvia aegyptiaca (Lamiaceae). Arch Biol Sci 68:291-301. https://doi.org/10.2298/abs150602018j 
Jiang J, Yuan X, Wang T, Chen H, Zhao H, Yan X, Wang Z, Sun X, Zheng Q (2014) Antioxidative and cardioprotective effects of total flavonoids extracted from Dracocephalum moldavica L. against acute ichemia/reperfusion-induced myocardial injury in isolated rat heart. Cardiovasc Toxicol 14:74-82. https://doi.org/10.1007/ s12012-013-9221-3

Johansen DA (1940) Plant microtechnique, 1st edn. McGraw Hill, New York

Kakasy AZ, Lemberkovics E, Kursinszki L, Janicsak G, Szoke E (2002) Data to the phytochemical. Herba Pol 48(3):112-119

Karnovsky MJ (1965) A formaldehyde-glutaraldehyde fixative of high osmolarity for use electron microscopy. J Cell Biol 27:137-138A

Konarska A (2016) Comparative micromorphology and anatomy of flowers and floral secretory structures in two Viburnum species. Protoplasma 254:523-537. https://doi.org/10.1007/s0070 9-016-0972-0

Kubiak M (1959) Pszczelnik mołdawski (Dracocephalum moldavicum L.) jako roślina cytrolowa. Acta Pol Pharm XVI 2:141-151

Lawrence BM (1992) Chemical components of Labiatae oils and their exploitation. In: Harley RM, Reynolds T (eds) Advances in Labiatae science. The Royal Botanical Gardens, Kew, Richmond, pp 399-436

Leal-Costa MV, Nascimento LBS, Moreira NS, Reinert F (2010) Influence of blue light on the leaf morphoanatomy of in vitro Kalanchoe pinnata (Lamarck) Persoon (Crassulaceae). Microsc Microanal 16:576-582. https://doi.org/10.1017/s1431927610000279

Lipiński M (2010) Pożytki pszczele. Zapylanie i miododajność roślin. Powszechne Wydawnictwo Rolnicze i Leśne, Warszawa, Wyd Sądecki Bartnik, Stróże

Liu M-Q, Liu J-F (2012) Structure and histochemistry of the glandular trichomes on the leaves of Isodon rubescens (Lamiaceae). Afr J Biotechnol 11:4069-4078

Lyapunowa PN, Salo ND, Sergienko TA (1975) An anatomical study of herb Dracocephalum moldavica L. Farmatsiia 24:15-20

Mabry TJ, Markham KR, Thomas MB (1970) The systematic identification of flavonoids. Springer, Berlin

Mass Spectral Library (2008) NIST/EPA/NIH, USA

Metcalfe CR, Chalk L (1972) Anatomy of the dicotyledons, vol 2. Clarendon Press, Oxford

Miguel MG (2010) Antioxidant and anti-inflammatory activities of essential oils: a short review. Molecules 15:9252-9287. https:// doi.org/10.3390/molecules 15129252

Moreira NS, Nascimento LBS, Leal-Costa MV, Tavares ES (2012) Comparative anatomy of leaves of Kalanchoe pinnata and K. crenata in sun and shade conditions, as a support for their identification. Braz J Pharmacogn 22:929-936. https://doi.org/10.1590/ s0102-695x2012005000056

Nikitina AS, Popova OI, Ushakova LS, Chumakova VV, Ivanova LJ (2008) Studies of the essential oil of Dracocephalum moldavica cultivated in the Stavropol Region. Pharm Chem J 42:203-207. https://doi.org/10.1007/s11094-008-0092-Z

Nikolakaki A, Christodoulakis NS (2004) Leaf structure and cytochemical investigation of secretory tissues in Inula viscosa. Bot J Linn Soc 144:437-448. https://doi.org/10.111 1/j.1095-8339.2003.00264.x

Nurzyńska-Wierdak R, Bogucka-Kocka A, Szymczak G (2014) Volatile constituents of Melissa officinalis leaves determined by plant age. Nat Prod Commun 9:703-706

O'Brien TP, McCully ME (1981) The study of plant structure: principles and selected methods. Thermacarphi Pty Ltd, Melbourne

Ramalingan K, Ravindranath MH (1970) Histochemical significance of green metachromasia to toluidine blue. Histochemie 24:322-327

Ruszkowski A, Zadura M, Biliński M, Gosek J, Kaczmarska K, Wojdaszka J (1997) Letni wzorzec składu gatunkowego trzmieli (Bombus Latr.) na różnych roślinach. Pszczelnicze Zesz Nauk 41:53-62
Rutkowski L (2006) Klucz do oznaczania roślin naczyniowych Polski niżowej. Wydawnictwo Naukowe PWN, Warszawa

Schultze W, Zaglein A, Hose S, Kubeczka KH, Czygan FC (1992) Volatiles in flowers of balm (Melissa officinalis L.). In: Harley RM, Reynolds T (eds) Advances in Labiate Science. Royal Botanic Gardens, Kew, Richmond, pp 357-366

Serrato-Valenti G, Bisio A, Cornara L, Ciarallo G (1997) Structural and histochemical investigation of the glandular trichomes of Salvia aurea L. leaves, and chemical analysis of the essential oil. Ann Bot 79:329-336

Shavarda AL, Telepova MN, Budantzev AL (1990) Srawnitielnoje izuczenie sostawa efirnych maseł i ultrastruktury železistych wołoskow lista u niekotorych Widow v. Dracocephalum L. Rast. Resursy 3:352-362

Shuge T, Xiaoying Z, Fan Z, Dongqing A, Tao Y (2009) Essential oil composition of the Dracocephalum moldavica L. from Xinjiang in China. Pharmacogn Res 1:172-174

Simmonds MSJ, Blaney WM (1992) Labiatae-insect interactions: effects of Labiatae-derived compounds on insect behaviour. In: Harley RM, Reynolds T (eds) Advances in Labiatae science. Royal Botanic Gardens, Kew, Richmond, pp 375-392

Stpiczyńska M, Davies KL, Pacek-Bieniek A, Kamińska M (2013) Comparative anatomy of the floral elaiophore in representatives of the newly re-circumscribed Gomesa and Oncidium clades (Orchidaceae: Oncidiinae). Ann Bot 112:839-854. https://doi. org/10.1093/aob/mct149

Sulborska A, Weryszko-Chmielewska E, Chwil M (2012) Micromorphology of Rosa rugosa Thunb. petal epidermis secreting fragrant substances. Acta Agrobot 65:21-28. https://doi. org/10.5586/aa.2012.018

Sulborska A, Dmitruk M, Konarska A, Weryszko-Chmielewska E (2014) Adaptations of Lamium album L. flowers to pollination by Apoidea. Acta Sci Pol Hortorum Cultus 13:31-43

Sultan A, Bahang Aisa HA, Eshbakova KA (2008) Flavonoids from Dracocephalum moldavica. Chem Nat Compd 44:366-367. https://doi.org/10.1007/s10600-008-9065-4

Taiz L, Zeiger E (2002) Plant Physiology, 3rd edn. Sinauer Associates Inc, Sunderland

Tantry MA, Bhat GA, Idris A, Dar JA, Yousef Al Omar S, Masoodi KZ, Bashir A, Ganai BA, Kamili AN, Shawl AS (2014) Sulfated triterpenes from Lemon balm. Helv Chim Acta 97:1497-1506. https://doi.org/10.1002/hlca.201400001

Tattini M, Matteini P, Saracini E, Traversi ML, Giordano C, Agati G (2007) Morphology and biochemistry of non-glandular trichomes in Cistus salvifolius L. leaves growing in extreme habitats of Mediterranean Basin. Plant Biol 9:411-419. https://doi. org/10.1055/s-2006-924662

Telepova MN, Budantzev AL, Sherarda AL (1992) Etude comparative de la sécrétion des terpènes par les éléments glandulaires foliaires chez différentes espèces du genre Dracocephalum L. (Labiatae). Bull Soc Bot Fr Lett Bot 139:247-264

Tozin LRS, Rodrigues TM (2017) Morphology and histochemistry of glandular trichomes in Hyptis villosa Pohl ex Benth. (Lamiaceae) and differential labeling of cytoskeletal elements. Acta Bot Bras 31:330-343. https://doi.org/10.1590/0102-33062016ab b0292

Tozin LRS, Silva SCM, Rodrigues TM (2016) Non-glandular trichomes in Lamiaceae and Verbenaceae species: morphological and histochemical features indicate more than physical protection. New Zeal J Bot. https://doi.org/10.1080/0028825X.2016.1205107

Van Den Dool H, Kratz PD (1963) A generalization of the retention index system including linear temperature programmed gas-liquid partition chromatography. J Chromat 11:463-471

Weryszko-Chmielewska E, Chwil M (2016) Flowering biology and structure of floral nectaries in Galanthus nivalis L. Acta Soc Bot Pol 85:3486. https://doi.org/10.5586/asbp.3486 
Weryszko-Chmielewska E, Sulborska A (2012) Diversity in the structure of the petal epidermis emitting fragrance compounds in Viola $\times$ witrockiana Gams. Acta Sci Pol Hortorum Cultus 11:155-167

Whitney HM, Chittka L, Bruce TJA, Glover BJ (2009) Conical epidermal cells allow bees to grip flowers and increase foraging efficiency. Curr Biol 19:948-953. https://doi.org/10.1016/j. cub.2009.04.051

Yoshitama K (2000) Recent advances in secondary metabolism research: regulation of biosynthesis and physiological functions of flavonoids and some phenolic. J Plant Res 113:285. https://doi. org/10.1007/PL00013939
Zhang M, Swarts SG, Yin L, Liu C, Tian Y, Cao Y, Swarts M, Yang S, Zhang SB, Zhang K, Ju S, Olek DJ, Schwartz JL, Keng PC, Howell R, Zhang L, Okunieff P (2011) Antioxidant properties of quercetin. Adv Exp Med Biol 701:283-289. https://doi. org/10.1007/978-1-4419-7756-4_38

Publisher's Note Springer Nature remains neutral with regard to jurisdictional claims in published maps and institutional affiliations. 